\title{
Kehadiran Tuhan di Tengah Umat-Nya: Dari Penciptaan ke Penciptaan yang Baru
}

\section{The Presence of God among His People: From the Creation to the New Creation}

\author{
Martus A. Maleachi, ${ }^{1{ }^{*}}$ Hendra Yohanes ${ }^{2)}$ \\ ${ }^{1)}$ Sekolah Tinggi Teologi SAAT, Malang \\ 2) Program Studi Magister Teologi Sekolah Tinggi Teologi SAAT, Malang \\ ${ }^{*}$ Korespondensi: mmaleachi@seabs.ac.id
}

\begin{abstract}
Abstrak: Di dalam studi dan teologi biblika, pertanyaan sentral yang masih didiskusikan sampai dewasa ini adalah apakah tema atau motif Alkitab yang dapat mempersatukan alur cerita dari Perjanjian Lama sampai Perjanjian Baru? Tulisan ini mengusulkan motif kehadiran Tuhan sebagai jawabannya, yakni kehadiran Allah yang berdiam di antara umat-Nya. Tuhan yang rindu untuk dekat dengan umat-Nya dengan menyatakan kehadiran di tempat-tempat kudus di sepanjang catatan Alkitab. Dengan menggunakan studi kata, studi intertekstual dalam kanon Alkitab, dan studi ekstrabiblika; tulisan ini menunjukkan bahwa kehadiran-Nya dipusatkan di tempat-tempat kudus yang didirikan-Nya di dalam dunia ini mulai dari Taman Eden pada penciptaan yang pertama, Kemah Suci, Bait Allah, gereja, sampai kepada penciptaan langit dan bumi yang baru. Artikel ini bertujuan menyajikan suatu gambaran alkitabiah tentang kehadiran Allah di tengah-tengah umat-Nya dan implikasinya bagi kehidupan Kristiani.
\end{abstract}

Kata-kata kunci: Eden, Penciptaan, Kehadiran Allah, Umat Allah, Penciptaan Baru, Tempat Kudus, Bait Suci

Abstract: In biblical studies and biblical theology, a central question still discussed until today is the following: what theme or motif can unify the biblical storyline from Old Testament to New Testament? This article proposes that the motif of the presence of God, who indwells among His people, as the answer. God, who desires to be near to His people, reveals His presence in holy places across biblical accounts. By using word studies, intertextual studies in the canonical bible, and extrabiblical studies, this article demonstrates that God's revealing of His presence, focused in holy places that He established in this world, began from the Garden of Eden in the first creation and extended through the Tabernacle, the Temple, the Church, to the creation of the new heaven and earth. The purpose of this article is to present a biblical overview of the presence of God among His people and its implications for the Christian life.

Keywords: Eden, Creation, Presence of God, People of God, New Creation, Sanctuary, Temple 


\section{PENDAHULUAN}

Di dalam studi teologi biblika, berbagai tema telah diusulkan sebagai tema yang mempersatukan Alkitab dari Perjanjian Lama (PL) hingga Perjanjian Baru (PB). John $\mathrm{H}$. Walton, seorang sarjana Perjanjian Lama, memberikan beberapa contoh pusat dari teologi Perjanjian Lama yang diusulkan para sarjana PL seperti: kovenan atau perjanjian (Walther Eichrodt), janji (Walter Kaiser), kerajaan (Bruce Waltke, Peter Gentry), komunitas (Brevard Childs), dan keselamatan (Geerhardus Vos). ${ }^{1}$ Sementara itu, salah satu problem yang banyak dikaji dalam teologi Perjanjian Baru adalah bagaimana kaitan atau kontinuitas PB dengan PL. Kesinambungan tema dari PL ke PB yang diusulkan oleh William Dumbrell adalah penciptaan dan penciptaan baru (new creation), sedangkan Charles H. Scobie mengusulkan pendekatan yang multitematik, yakni: tatanan ciptaan Allah-Hamba Allah-Umat Allahjalan Allah atau etika. ${ }^{2}$ Pertanyaannya yang muncul adalah apakah tema atau motif Alkitab yang dapat mempersatukan alur cerita dari PL sampai PB?

Salah satu tema yang dapat mempersatukan teologi biblika adalah motif kehadiran Allah di tempat kediaman-Nya, atau kehadiran Allah yang berdiam di tengah-tengah umatNya. ${ }^{3}$ Di dalam dunia yang penuh dengan tantangan, seperti pandemi global yang disebabkan virus Corona, umat Kristen juga

${ }^{1}$ Selengkapnya, lih. John H. Walton, Old Testament Theology for Christians: From Ancient Context to Enduring Belief (Downers Grove: InterVarsity, 2017), 24-25.

${ }^{2}$ G.K. Beale, A New Testament Biblical Theology: The Unfolding of the Old Testament in the New (Grand Rapids: Baker Academic, 2011), bab 1.

${ }^{3}$ Walton sendiri berpandangan bahwa kehadiran $\mathrm{Al}-$ lah di antara dan relasi dengan umat-Nya merupakan fokus dan alur cerita Kitab Suci dari awal sampai akhir (lih. Walton, Old Testament Theology, 26-28). Sedangkan, pembacaan tema tempat kediaman Allah mulai dari PL sampai PB juga diteliti oleh Gregory Beale. Lih. G.K. Beale, The Temple and the Church's Mission: A Biblical Theology of the Dwelling Place of God, New Studies in Biblical Theology (Downers Grove: InterVarsity, 2004). bergumul dengan kekuatiran dan kebimbangan akan kehadiran Tuhan. ${ }^{4}$ Akan tetapi, Alkitab secara konsisten menunjukkan kerinduan Tuhan untuk hadir dan menyertai umat-Nya melalui kehadiran di tempat-tempat kudus di sepanjang catatan Alkitab. Kehadiran-Nya dipusatkan di tempat kudus yang didirikan-Nya di dalam dunia ini mulai dari Taman Eden pada penciptaan yang pertama sampai kepada penciptaan langit dan bumi yang baru.

Pertanyaan yang mungkin timbul adalah apakah Allah juga hadir untuk menyertai umat-Nya setelah kejatuhan manusia ke dalam dosa? Meskipun manusia berdosa dan telah diusir dari Eden, Allah tetap berulangulang kali hadir dan memelihara umat-Nya. Secara khusus, kitab Kejadian menunjukkan hal ini melalui toledot (silsilah-silsilah) yang tidak terputus dari Adam melalui Set, Sem, Abraham sampai kepada umat pilihan Allah (Kej. 5:1-32 dan 11:10-26; bdk. juga Luk. 3:23-38). ${ }^{5}$ Selain itu, Alkitab juga mencatat bahwa Allah memelihara umat-Nya dengan menebus umat Israel dari negeri Mesir dan menuntun mereka melalui perjalanan di padang gurun dengan Kemah Suci yang menjadi tempat kudus yang menyatakan kehadiran YHWH di tengah-tengah umatNya (Kel. 25:8-9; 29:43-46). Di dalam sejarah perjalanan umat Israel berikutnya,

${ }^{4}$ Pada tanggal 11 Maret 2020, WHO mengumumkan secara resmi wabah virus Corona sebagai pandemi global (Philippa Roxby, "Coronavirus Confirmed as Pandemic," $B B C$ News, Maret 11, 2020, diakses 4 Mei 2020, https://www.bbc.com/news/world-51839944).

${ }^{5}$ Sebagai contoh, mereka yang hidup dekat dan taat kepada-Nya seperti ditunjukkan keturunan Adam melalui garis keturunan Set yang mencari Tuhan dan mulai memanggil nama "TUHAN" (Kej. 4:26) dan juga Nuh yang bergaul dengan Allah dan hidup tidak bercela (Kej. 6:9) serta mendirikan mezbah bagi YHWH (Kej. 8:20). Allah juga secara khusus memanggil dan menjumpai para bapa leluhur, seperti: Abraham mendirikan mezbah di More dan di antara Betel dan Ai (Kej. 12:7-8), Ishak mendirikan mezbah di Bersyeba (Kej. 26:23-25), dan Yakub mendirikan tugu di Betel (Kej. 28:16-19; 31:13). Allah menyatakan kehadiran dan penyertaan-Nya kepada mereka. 
Allah memerintahkan pembangunan Bait Suci sebagai tempat peribadatan umat pilihan Allah (1 Raj. 5-6). Di Perjanjian Baru, jemaat Tuhan disebut sebagai "bait Allah" (1 Kor. 3:16-17) dan "bait Roh Kudus" (1 Kor. 6:19). Alkitab ditutup dengan kitab Wahyu yang merekam visi Yerusalem yang baru sebagai kota yang kudus di langit dan bumi yang baru (Why. 21-22). Di sepanjang Alkitab, tema mengenai Bait Suci atau tempat kehadiran Allah di tengah-tengah umat-Nya bermunculan secara konsisten.

Tulisan ini bertujuan untuk memberikan gambaran alkitabiah (biblical overview) tentang kehadiran Allah bersama dengan umatNya dan implikasinya bagi kehidupan Kristiani. Pendekatan eksegesis dan tafsir yang digunakan terhadap beberapa teks Alkitab adalah studi kata, studi intertekstual dalam kanon Alkitab, dan juga studi ekstrabiblika yang memperjelas pemahaman teks tersebut. Pembahasan akan dibagi sesuai dengan kronologi kehadiran Tuhan di tempat kudusNya yang dimulai dari Taman di Eden, Kemah Suci, Bait Allah, gereja setelah inkarnasi, kematian dan kebangkitan Kristus, dan sampai kepada langit dan bumi yang baru.

\section{PENELUSURAN MOTIF BIBLIKA KEHADIRAN TUHAN}

\section{Kehadiran Allah di Taman di Eden}

Pada umumnya ketika kita membaca kisah penciptaan manusia dan penempatannya di Taman (Firdaus) di Eden, kita akan memahami taman itu sebagai tempat yang indah dan damai di mana semua makhluk ciptaan Tuhan dapat hidup dengan harmonis. Sesungguhnya, keindahan yang terutama dari taman di Eden adalah kehadiran Allah. Taman ini adalah tempat kudus Allah yang pertama (the first sanctuary) di bumi ini. ${ }^{6}$

${ }^{6}$ Lih. Lifsa Schachter, "The Garden of Eden as God's First Sanctuary," Jewish Bible Quarterly 41, no. 2 (April 2013): 73-77.
Kejadian 2:8 menunjukkan bahwa lokasi taman ini adalah di sebelah timur Eden. ${ }^{7}$ Seperti tempat kudus yang biasanya ada di tempat tinggi (bdk. Yeh. 28:13-14), taman ini juga berlokasi di dataran tinggi. Kejadian 2:10 menunjukkan bahwa ada sungai yang mengalir dari Eden menuju ke taman ini dan terbagi ke dalam empat penjuru. Sungai selalu mengalir dari tempat yang lebih tinggi ke tempat yang lebih rendah. Di tengah taman ini ada pohon pengetahuan yang baik dan yang jahat serta pohon kehidupan. Jalan masuk ke dalam taman itu ada di sebelah timur. Setelah manusia pertama jatuh ke dalam dosa, maka jalan masuk ke dalam taman ini dijaga oleh kerub dengan pedang yang bernyala-nyala. Hal ini menunjukkan bahwa taman ini memiliki pembatas dan hanya dapat dimasuki dari sebelah timur. ${ }^{8}$

Selain lokasinya, ada beberapa petunjuk yang memperjelas bahwa taman di Eden adalah tempat kudus Allah. Pertama, kehadiran kerub (jamak: kerubim) di taman ini menegaskan bahwa taman ini adalah tempat kudus Allah (Kej. 3:24). Kerub, sebagaimana diungkapkan oleh Wenham, adalah penjaga

\footnotetext{
${ }^{7}$ Kejadian 2:8 menjelaskan bahwa lokasi dari taman itu adalah di sebelah timur Eden. Ini berarti Eden adalah daerah yang lebih luas dari taman itu atau dapat dikatakan bahwa taman itu berlokasi di Eden. Lih. Daniel I. Block, "Eden: A Temple? A Reassessment of the Biblical Evidence," dalam From Creation to New Creation: Biblical Theology and Exegesis, Essays in honor of G.K. Beale, ed. Daniel M. Gurtner dan Benjamin L. Gladd (Peabody: Hendrickson, 2013), 16.

${ }^{8}$ Taman dalam bahasa-bahasa yang serumpun dengan bahasa Ibrani mengandung pengertian sebagai tempat yang dilindungi atau memiliki pagar (lih. Ludwig Koehler dan Walter Baumgartner, The Hebrew and Aramaic Lexicon of the Old Testament, s.v. "Ia”). Peter J. Gentry menje-laskan bahwa dalam Perjanjian Lama, taman kerajaan dikelilingi oleh pagar (2 Raj. 25:4; Neh. 3:15; Yer. 39:4; 52:7). Kata yang dipakai Septuaginta menerjemahkan kata "taman" adalah $\pi \alpha \rho \alpha ́ \delta \varepsilon เ \sigma o \varsigma$ (Firdaus). Kata ini berasal dari bahasa Persia yang berarti taman yang menyenangkan yang dikelilingi oleh pagar batu atau tanah liat. Bdk. Peter J. Gentry, "Kingdom through Covenant: Humanity as The Divine Image," The Southern Baptist Journal of Theology 12, no. 1 (2008): 3738; Robert Hinckley, "Adam, Aaron, and the Garden Sanctuary,” Logia 22, no. 4 (2013): 6.
} 
dari tempat kudus dalam pemahaman dunia Timur Dekat Kuno. Kerub kemudian muncul sebagai penjaga ruang maha kudus dalam Bait Suci (1 Raj. 6:23-28). Kerub juga adalah penjaga tutup pendamaian di tabut perjan-jian (Kel. 25:18-22). Gambaran dari kerubim muncul di dalam dekorasi dari tiraitirai baik di Kemah Suci maupun Bait Allah (Kel. 26:31; 1 Raj. 6:29). ${ }^{9}$

Kedua, kata yang dipakai untuk melukiskan bahwa Allah biasa berjalan-jalan di dalam

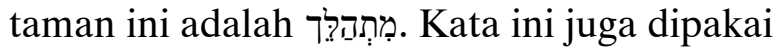
untuk menggambarkan kehadiran Allah di Kemah Suci (Im. 26:12; U1. 23:15; 2 Sam.7:67). ${ }^{10}$ Allah hadir di tempat kudus-Nya untuk bersama dengan umat-Nya. Hal ini telah dilakukan-Nya sejak awal penciptaan dunia.

Ketiga, tugas yang diberikan oleh Allah kepada Adam adalah untuk menjaga dan mengusahakan taman itu. Dalam bahasa Ibrani, kata yang dipakai di Kejadian 2:15

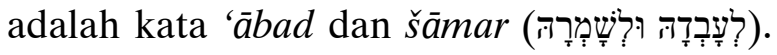
Kata 'ābad dipakai untuk suatu pekerjaan yang berkaitan dengan ibadah. Alasan yang Musa berikan kepada Firaun untuk membawa bangsa Israel keluar dari Mesir adalah agar mereka dapat beribadah ('ābad) di padang gurun (Kel. 7:16). Kata ini juga dipakai untuk membangun Kemah Suci (Kel. 35:24; 39:42) dan pelayanan di Kemah Suci

\footnotetext{
${ }^{9}$ Gordon Wenham, "Sanctuary Symbolism in the Garden of Eden Story," in I Studied Inscriptions from Before the Flood: Ancient Near Eastern, Literary, and Linguistic Approaches to Genesis 1-11, ed. Richard S. Hess dan David Toshio Tsumura (Winona Lake: Eisenbrauns, 1994), 401. Bentuk dari kerub sendiri tidak diketahui dengan pasti. Gambaran yang didapat dari Alkitab maupun dari penggambaran (iconography) dunia Timur Dekat Kuno menunjukkan kerub adalah makhluk bersayap. Keluaran 25:18-20; 37:7-9 dan 1 Raja-raja 6:23-26 menggambarkan bahwa makhluk ini dalam posisi berdiri yang memberikan gambaran bahwa kemungkinan makhluk bersayap ini dalam rupa manusia atau burung. Lih. Raanan Eichler, "Cherub: A History of Interpretation," Biblica 96, no. 1 (2015): 26-38, khususnya bagian kesimpulan halaman 37-38. Eichler berpendapat bahwa kerub yang dilukiskan dalam Yehezkiel 8-11 merupakan makhluk yang berbeda (ibid., 26).

${ }^{10}$ Wenham, "Sanctuary Symbolism," 400-401.
}

(Bil. 3:8; 8:26; 18:6). Sedangkan kata šāmar, yang berarti memperhatikan, biasanya dipakai untuk memperhatikan hari Sabat (Kel. 31:13). ${ }^{11}$ Kedua kata ini muncul bersamaan dalam Bilangan 3:7-8; 8:26; dan 18:5-6 dalam penjabaran tugas orang Lewi di dalam melayani dan menjaga tempat kudus. ${ }^{12}$ Berdasarkan dari pemahaman akan pemakaian kata-kata ini, maka tugas Adam bukanlah sekadar sebagai seorang penjaga taman yang memelihara dan mengolah taman itu melainkan sebagai penjaga tempat kudus Allah yang pertama, yakni taman di Eden.

Keempat, beberapa deskripsi dari taman di Eden, seperti emas dan batu-batu berharga diulangi di berbagai bagian lain dari Alkitab untuk menggambarkan bahan-bahan berkualitas yang dipakai untuk membangun tempat kudus Allah selanjutnya. Di dalam taman di Eden digambarkan bahwa emas yang baik, damar bedolah (פָּדּלָ) dan batu krisopras atau oniks (نic) ada di tanah Hawila (Kej. 2:11-12). Emas, sebagai logam mulia, banyak dipakai untuk membuat perkakas dalam ruang maha kudus di Kemah Suci (Kel. 25:10-40) dan Bait Allah (1 Raj. 7:48-50). Emas bahkan digunakan untuk melapisi interior dari ruang mahakudus di Bait Allah (1 Raj. 6:20-22). Sedangkan batu krisopras ini dipakai untuk menuliskan nama dari kedua belas suku Israel di pakaian imam dan juga mendekorasi baju imam, Kemah Suci dan Bait Allah (Kel. 25:7; 28:9, 20; 1 Taw. 29:2). ${ }^{13}$ Batu berharga ini juga dipakai sebagai fondasi Bait Allah dan di kemudian hari disebutkan sebagai fondasi dari Yerusalem yang baru di langit dan bumi yang baru (Why. 21:19-20). ${ }^{14}$

\footnotetext{
${ }^{11}$ Hinckley, "Adam, Aaron,” 7.

${ }^{12}$ Bdk. Schachter, "The Garden of Eden," 75; Beale, Temple and Church's Mission, 67.

${ }^{13}$ Wenham, "Sanctuary Symbolism," 402. Selain itu, damar bedolah di dalam Bilangan 11:7 dipakai untuk menggambarkan manna atau roti dari surga (Hinckley, "Adam, Aaron," 6).

${ }^{14}$ Beale, Temple and Church's Mission, 24.
} 
Kehadiran Allah di Taman Eden menunjukkan bahwa tempat ini merupakan tempat kudus. Fakta-fakta yang diberikan di atas menunjukkan gambaran yang jelas bahwa taman di Eden adalah tempat kudus Allah yang pertama. Dengan demikian, taman ini adalah ruang mahakudus di mana Allah hadir untuk bersekutu dengan umat-Nya sebelum mereka jatuh ke dalam dosa. ${ }^{15}$

\section{Kehadiran Allah dalam Kemah Suci}

Tempat kudus yang menjadi tempat pertemuan antara Allah dengan manusia selanjutnya adalah Kemah Suci (Tabernacle). Allah hadir di dalam tempat kudus yang dibuat sesuai dengan rancang bangun yang diberikan oleh-Nya. Kemah Suci dibangun berdasarkan blueprint atau diagram (תָרְנִית) dari tempat kudus Allah di surga (Kel. 25:8-9, 40; 26:30; 27:8; Bil. 8:4; bdk. Mzm. 11:4; Ibr. 9:24). ${ }^{16}$ Kemah Suci merupakan tempat kehadiran Allah di tengah-tengah umat-Nya. Tugas pertama dari Israel sebagai bangsa yang telah dipilih menjadi umat Allah adalah membangun tempat kudus Allah, yakni Kemah Suci. Allah yang Mahakudus membatasi diri-Nya agar dapat tinggal di tengahtengah umat-Nya yang berdosa. ${ }^{17}$

${ }^{15}$ Bdk. John H. Walton, Genesis 1 as Ancient Cosmology, (Winona Lake: Eisenbrauns, 2011), 186 dan Block, "Eden: A Temple?," 16-17. Penggambaran ini lebih tepat daripada pendapat Beale bahwa Eden adalah ruang mahakudus sedangkan taman itu adalah ruang kudus. Ia menjelaskan bahwa kehadiran pohon kehidupan dan melimpahnya makanan di taman sejajar dengan kandil dan meja roti dalam ruang kudus di Kemah Suci atau Bait Allah (Beale, Temple and Church's Mission, 74-75). Pembagian yang detail tentang tempat kudus Allah seperti tiga bagian Kemah Suci atau Bait Allah tidak diperlukan untuk mengerti bahwa taman di Eden adalah tempat kudus Allah yang pertama. Mengingat keadaan manusia pertama pada waktu tinggal di taman itu adalah sebelum kejatuhan, maka kesejajaran yang tepat adalah tempat kehadiran Allah bersama dengan umat yang telah disucikan-Nya dalam langit dan bumi yang baru. Lihat bagian "Kehadiran Allah dalam Langit dan Bumi yang Baru."

${ }^{16}$ Lih. Jon D. Levenson, Sinai and Zion: An Entry into the Jewish Bible (San Francisco: Harper, 1987), 140 dan Walton, Old Testament Theology, 121.

${ }^{17}$ Daniel R. Hyde, God in Our Midst: The Tabernacle and Our Relationship with God (Sanford: Reformation Trust, 2012), 61.
Pintu masuk Kemah Suci, sama seperti Taman di Eden, yaitu dari timur (Kel. 27:13; bdk. Kej. 3:24). Arah ini juga merupakan pintu masuk yang sama untuk Bait Allah Salomo dan juga Bait Allah menurut penglihatan nabi Yehezkiel (Yeh. 40:6). ${ }^{18}$ Kemah Suci terdiri dari tiga bagian: pelataran, ruang kudus dan ruang mahakudus. Di dalam ruang kudus terdapat meja roti sajian, kandil, dan mezbah ukupan. Semua benda-benda yang ada di dalam ruang kudus ini dibuat dari emas (Kel. 25:11-39; 30:1-10). Ruang kudus dan ruang mahakudus dipisahkan oleh tirai yang memiliki bordiran kerub. Kehadiran kerub di dalam tirai ini menunjukkan bahwa mereka menjaga jalan masuk ke tempat kudus ilahi. Dalam hal ini, kerub menjaga jalan ke ruang mahakudus (bdk. Kej. 3:24).

Di dalam ruang maha kudus terdapat tabut perjanjian (the ark of the covenant) yang terbuat dari emas. Tabut ini merupakan simbol kehadiran Allah dan singgasana Allah di dalam dunia ini (1 Sam. 4:4; 1 Taw. 28:2; Mzm. 99:5; 132:7-8, 13-14). ${ }^{19}$ Pada waktu mereka berjalan di padang gurun, tabut itu harus terlihat sebagai perwujudan dari kehadiran Tuhan sebagai raja Israel. Oleh sebab itu, gelang dari tabut tersebut harus berada di kaki tabut sehingga pada waktu dipikul tabut itu terlihat jelas oleh seluruh bangsa Israel (Kel. 25:12-14). ${ }^{20}$ Melalui tabut perjanjian ini, Allah bertemu dan berbicara kepada umat-Nya (Kel. 25:22).

\footnotetext{
${ }^{18}$ Beale, Temple and Church's Mission, 74.

${ }^{19}$ Dalam Mazmur 132:7 menunjukkan bahwa tempat

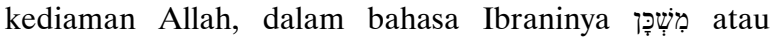
Kemah Suci, adalah tempat tumpuan kaki atau ruang takhta Allah. Selanjutnya, di ayat 8 dikatakan bahwa tabut perjanjian adalah singgasana Allah (bdk. 1 Taw. 28:2). Lih. John H. Walton, The Lost World of Genesis One (Downers Grove: IVP Academic, 2009), 73-74.

${ }^{20}$ Hyde, God in Our Midst, 62. Kesalahan Daud pada waktu memindahkan tabut ke Yerusalem adalah dengan membawanya di atas kereta. Itulah sebabnya Tuhan marah dan mengakibatkan Uza terbunuh. Tabut Allah seharusnya dipikul oleh orang Lewi (lih. 2 Sam. 6:1-11, 13; 1 Taw. 15:15; Bil. 7:9).
} 
Kesinambungan antara taman di Eden dan Kemah Suci terlihat dari beberapa unsur. Menurut Keluaran 26:31, warna-warni tirai yang memisahkan ruang kudus dan mahakudus adalah ungu tua (purple), ungu muda (blue), dan kirmizi (scarlet) dengan bordiran kerub (bdk. Kej. 3:24). ${ }^{21}$ Sedangkan tiraitirai lainnya juga memiliki warna yang sama (Kel. 26:36; 27:16; 36:37; 38:18). Demikian juga beberapa bagian lain dari kemah tersebut (Kel. 36:11). Selain itu, seluruh perkakas Kemah Suci ditutup dengan kain biru pada waktu pengangkutan (Bil. 4:5-13). ${ }^{22}$ Warna-warna itu menggambarkan alam semesta. Warna kirmizi kemungkinan besar menggambarkan api dari petir ataupun matahari, sedangkan ungu tua menggambarkan awan yang pekat dan biru menggambarkan langit. ${ }^{23}$ Semua warna ini terlihat dari dalam Kemah Suci. Selain itu, asap yang timbul dari mezbah ukupan memenuhi kemah itu seperti asap yang menyatakan kehadiran Tuhan di gunung Sinai (Kel. 19:9; bdk. 19:16, $18 ; 20: 18) .^{24}$

Unsur yang lain terlihat adalah kandil atau

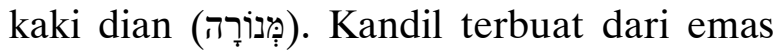
murni dan memiliki ukiran yang melambangkan pohon yang memiliki tujuh cabang. Tiga cabang di satu sisi dan tiga di sisi lainnya. Sedangkan di tengah-tengahnya ada satu cabang yang tegak berdiri. Kandil tersebut memiliki ukiran seperti pohon yang memiliki batang dan kelopak bunga badam atau almond (Kel. 25:31-40). Ketujuh cabang itu digambarkan keluar dari satu batang. Menurut Sarna, gambaran kandil yang seperti pohon ini merupakan representasi dari pohon

\footnotetext{
${ }^{21}$ Gambaran kerub juga ada di kain lenan Kemah Suci (Kel. 26:1). Bdk. J. Daniel Hays, The Temple and The Tabernacle: A Study of God's Dwelling Places from Genesis to Re-velation (Grand Rapids: Baker, 2016), 53.

${ }^{22}$ Alkitab terjemahan LAI-TB menerjemahkan warna kain di bagian ini menjadi "ungu tua," sedangkan ESV dan NRSV menerjemahkannya menjadi "blue." Penulis memi-lih terjemahan "biru" karena lebih tepat dalam mewakili warna langit.

${ }^{23}$ Beale, Temple and Church's, 38.

${ }^{24}$ Hyde, God in Our Midst, 83.
}

kehidupan. ${ }^{25}$ Terang dari kandil ini harus tetap menyala dari petang hingga pagi (Kel. 27:20-21). Menariknya, kata yang dipakai untuk penerangan dalam bagian ini (מָאוֹר) adalah kata yang dipakai untuk menggambarkan benda-benda penerang pada hari keempat dalam kisah penciptaan (Kej. 1:14-17; bdk. Kej. 1:3). ${ }^{26}$ Hal ini membawa kita kembali kepada kisah penciptaan di mana Tuhan menciptakan terang di tengah kegelapan alam semesta ini.

Hal yang terpenting adalah bagaimana kehadiran Allah dinyatakan di tengah-tengah Ke-

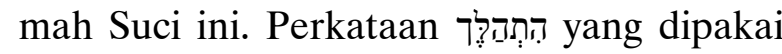
untuk menggambarkan kehadiran Allah di Taman (Kej. 3:8) juga dipakai di sini (bdk. Im. 26:12; Ul. 23:14; 2 Sam. 7:6-7). Selain itu, pasangan kata 'ābad dan šāmar juga dipakai bersama untuk menunjukkan bahwa Israel menyembah dan menaati atau memelihara firman Allah. Gabungan kata yang sama juga dipakai untuk menunjukkan pekerjaan seorang imam memelihara Kemah Suci (Bil. 3:7-8; 8:25-26; 18:5-6; 1 Taw. 23:32; Yeh. 44:14). ${ }^{27}$ Bukti di atas menunjukkan bahwa terdapat "replika" taman di Eden di dalam Kemah Suci. Di tempat kudus inilah, Tuhan hadir untuk bertemu dengan umat-Nya.

\section{Kehadiran Allah dalam Bait Allah}

Tempat kehadiran Tuhan di tengah umatNya setelah Kemah Suci adalah Bait Allah. Tempat kudus yang didirikan oleh Salomo ini adalah kelanjutan dan proyeksi dari

\footnotetext{
${ }^{25}$ Nahum Sarna, Exodus, The JPS Torah Commentary (Philadephia: The Jewish Publication Society, 1991), 165. Lih. juga Hays, The Temple, 47-48; G.K. Beale dan Mitchell Kim, God Dwells among Us: Expanding Eden to the Ends of the Earth (Downers Grove: InterVarsity, 2015), 19-20; Beale, Temple and Church's Mission, 71; dan Hyde, God in our Midst, 84.

${ }^{26}$ Walton, The Lost World, 80-81.

${ }^{27}$ Beale, Temple and Church's, 66-67.
} 
Kemah Suci. ${ }^{28}$ Sama seperti Musa, dalam catatan kitab Tawarikh, Daud juga menerima rancang bangun (תְְָּנית) dari Allah untuk petunjuk pembangunan Bait Suci (1 Taw. 28:11-19; bdk. Kel. 25:9, 40). Oleh karena itu, Bait Allah memiliki simbolisasi yang sama dengan Kemah Suci. Keduanya memiliki pelataran, ruang kudus dan ruang mahakudus.

Pemaparan selanjutnya mengenai Bait Allah akan difokuskan kepada unsur-unsur yang berkaitan dengan tempat kudus yang pertama di taman di Eden. Kesamaan di antara keduanya terlihat dengan banyaknya deskripsi berupa ukiran yang berbentuk labu dan bunga (1 Raj. 6:18), pohon korma dan bunga (1 Raj. 6:29, 32), buah delima (1 Raj. 7:20), dan bunga bakung (1 Raj. 7:22). Gambaran pepohonan, bunga dan buah juga ada di dalam "laut" dan kedua tiang tembaga di pelataran Bait Allah (7:24-26, 42). Di ruang kudus, ada sepuluh kandil yang digambarkan seperti pohon dengan bunganya (1 Raj. 7:49; bdk. Za.1:8-11; Mzm. 74:3-7). ${ }^{29}$

Gambaran hewan juga ada di pelataran Bait Allah. Di kesepuluh bejana pembasuhan ada gambar dari singa, lembu, dan kerub (1 Raj. 7:29). Sedangkan bejana besar yang dinamai "laut" memiliki gambar dua belas lembu (1 Raj. 7:23-26). ${ }^{30}$ Tiap tiga lembu menghadap ke empat penjuru mata angin (2 Taw. 4:2-5). Victor Hurowitz berpendapat bahwa "laut" ini merupakan gambaran dari sungai yang mengalir keluar dari Eden ke empat penjuru (Kej. 2:10). ${ }^{31}$ Semua gambaran ini menggam-

${ }^{28}$ Menahem Haran, Temples and Temple Service in Ancient Israel (Winona Lake: Eisenbrauns, 1985), 189192. Bait Suci dapat dikatakan adalah perluasan dari Kemah Suci. Hal ini terlihat dari pelipatgandaan bejana pembasuhan dan kandil yang berjumlah masing-masing sepuluh.

${ }^{29}$ Beale, Temple and Church's Mission, 72.

${ }^{30}$ Lih. Hays, The Temple, 96.

${ }^{31}$ Victor Avigdor Hurowitz, "YHWH's Exalted House-Aspects of the Design and Symbolism of Solomon's Temple," dalam Temple and Worship in Biblical Israel, ed. John Day (London: T\&T Clark, 2007), 80-81. barkan kembali kisah penciptaan. ${ }^{32}$ Sama dengan keadaan taman di Eden yang memiliki banyak batu berharga dan emas (Kej. 2:1112), demikian pula fondasi dari Bait Allah terdiri dari batu-batu mahal (1 Raj. 5:17) dan interiornya dilapisi oleh emas murni (1 Raj. 6:20-21). 1 Tawarikh 29:1-7 menggambarkan berbagai macam batu berharga seperti batu permata yang berwarna-warni, termasuk krisopras atau oniks (نغ (ن) yang dipakai untuk membangun Bait Allah. ${ }^{33}$ Menurut Beale, penggunaan batu mulia di dalam Bait Allah maupun hiasan pakaian kudus imam menggambarkan keindahan dan kemuliaan Allah (Kel. 28:2) sebagaimana kemilau batu mulia menggambarkan kemilau cahaya langit berbintang yang menunjuk kepada tempat kediaman Allah yang mulia. ${ }^{34}$

Hal yang penting juga untuk diperhatikan adalah adanya ruang kosong di atas ruang mahakudus. Bentuk dari ruangan ini adalah kubus, sehingga panjang, lebar dan tingginya adalah 20 hasta (1 Raj. 6:20) sedangkan tinggi Bait Suci adalah 30 hasta (1 Raj. 6:3). Di sini terlihat ada perbedaan 10 hasta. Untuk menjawab perbedaan ini, maka ada beberapa pendapat yang dikemukakan. Pertama, berdasarkan struktur dari bangunan ruang maha kudus yang terbuat dari kayu, Volkmar Fritz berpendapat bahwa ruang mahakudus ini adalah suatu bangunan tempat kudus (shrine) yang berbentuk kubus. Bangunan ini diletakkan di dalam Bait Allah untuk menyimpan tabut perjanjian. ${ }^{35}$ Pandangan kedua diberikan oleh John Monson. Berdasarkan kesamaan struktur dari kuil di Ain Dara, maka dia berpendapat

\footnotetext{
${ }^{32}$ Beale, Temple and Church's Mission, 34.

${ }^{33}$ Ibid., 40.

${ }^{34}$ Ibid., 41-42. Terjemahan LAI-TB dalam Keluaran 28:2 memuat "sebagai perhiasan kemuliaan" sebagaimana terjemahan NRSV "for the glorious adornment." Akan tetapi, terjemahan ESV dan RSV menerjemahkan menjadi "for glory and for beauty."

${ }^{35}$ Volkmar Fritz, "Temple Architecture: What Can Archaeology Tell Us About Solomon's Temple?" Biblical Archaeological Review 13, no. 4 (1987): 41.
} 
adanya sepuluh hasta (sekitar $5 \mathrm{~m}$ ) tangga menuju ke ruang mahakudus. ${ }^{36}$

2 Tawarikh 3:9 menyebutkan adanya kamar-

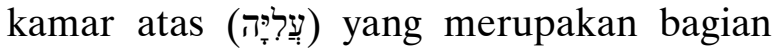
dari rancang bangun yang disampaikan oleh Daud (1 Taw. 28:11). Dari konteks dekatnya, maka kemungkinan ruangan ini berada di atas ruang mahakudus. Fakta bahwa ruangan ini dilapis dengan emas oleh Salomo menunjukkan bahwa ini adalah bagian penting dari Bait Allah. Menimbang bahwa di dalam Alkitab tidak ada catatan adanya tangga untuk masuk ke ruang mahakudus, maka kemungkinan besar memang di atas ruang mahakudus adalah kamar-kamar atas yang merupakan ruangan yang kosong. ${ }^{37}$ Jikalau demikian, apakah artinya adanya ruang kosong di atas tabut perjanjian? Beale berpendapat bahwa sangat mungkin ruang kosong di atas ruang maha kudus menggambarkan Allah yang tidak dapat dilihat. Tidak ada sesuatu pun yang dapat menggambarkan Dia. ${ }^{38}$ Allah yang seperti inilah yang bertakhta di dalam ruang mahakudus. Kehadiran kerub-kerub yang mengelilingi ruang itu menunjukkan ini adalah tempat Allah bertakhta (1 Raj. 6:23-28). Singga-sana Allah adalah tabut perjanjian (1 Taw. 28:2; Mzm. 99:5; 132:7-8; Yes. 66:1). Kekudusan dari ruang takhta Allah ini membuat ruang ini hanya boleh dimasuki oleh imam besar setahun sekali, itu pun dengan dilindungi oleh asap yang tebal dari mezbah ukupan agar dia tidak mati ketika melihat kemuliaan Allah (Im. 16:13). Ruang mahakudus adalah bayangan dari ruang takhta Allah di surga (Why. 4:7-11). Dengan demikian, ruang mahakudus dengan ruang kosong di atasnya

\footnotetext{
${ }^{36}$ John Monson, "The New Ain Dara Temple: Closest Solomon Parallel," Biblical Archaeological Review 26, no. 3 (2000): 31, 33.

${ }^{37}$ Hurowitz, "YHWH's Exalted House," 73.

${ }^{38}$ Beale, Temple and Church's, 36-37. Selain itu, fakta bahwa di dalam ruang maha kudus dari tempat kudus Israel tidak ditemukan patung memperkuat bukti bahwa yang membedakan antara Israel dengan bangsa-bangsa lain adalah Allah yang tidak terlihat namun hadir di tengah umat-Nya.
}

menggambarkan Allah yang tidak terlihat namun ingin hadir dan berdiam bersama dengan umat-Nya.

\section{Kehadiran Allah dalam Gereja setelah Inkarnasi, Kematian, dan Kebangkitan Kristus}

Inkarnasi Tuhan Yesus merupakan kelanjutan dari kehadiran Allah di dunia ini. Injil Yohanes 1:14 menyatakan bahwa Kristus tinggal berdiam atau berkemah

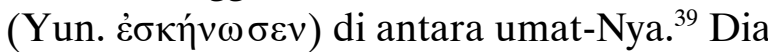
hadir untuk melaksanakan penebusan bagi umat-Nya. Kematian dan kebangkitan Kristus merupakan puncak dari rencana penebusan Allah. Pada waktu Tuhan Yesus disalib, tirai Bait Suci terbelah (Mat. 27:51; Mrk. 15:38; Luk. 23:45). Terbelahnya tirai ini menunjukkan bahwa Tuhan Yesus sebagai korban yang sempurna dan Imam Besar yang sempurna telah masuk ke tempat kudus Allah yang lebih besar dan lebih sempurna. Tempat kudus yang bukan buatan tangan manusia yang ada di dunia, tetapi di tempat kediaman Allah di surga untuk menebus manusia (Ibr. 9:11-12; 10:19-21). ${ }^{40}$ Inilah penebusan sejati sekali untuk selama-lamanya. Hal ini menunjukkan bahwa era persembahan korban di Bait Allah telah berakhir.

Peter Gentry memberikan pengamatan yang penting mengenai hasil dari penebusan Kristus. Berbeda dengan waktu penciptaan di mana Allah menyediakan tempat terlebih dahulu sebelum menciptakan manusia, maka dalam menyongsong penciptaan yang baru Allah terlebih dahulu mempersiapkan manusia yang akan tinggal di sana. ${ }^{41}$ Kristus

\footnotetext{
${ }^{39}$ Kata "berdiam" di sini merupakan kata yang sama yang dipakai dalam Septuaginta untuk merujuk "tabernakel" atau "kemah." Lih. Hyde, God in Our Midst, 30.

${ }^{40}$ Terbelahnya tabir Bait Suci ini pada saat kematian Kristus membuka akses umat manusia yang berdosa kepada hadirat Allah yang kudus. Bdk. Walton, Old Testament Theology, 123; Ryan S. Dennis, "The Temple of God and the Early Christian Church" (tesis, Reformed Theological Seminary, 2016), 32-33.

${ }^{41}$ Gentry, "Kingdom through Covenant," 33.
} 
yang bangkit, sebagai Adam yang kedua, adalah yang sulung dari semua ciptaan yang baru (1 Kor. 15:20-23). Oleh sebab itu, semua orang yang percaya kepada Kristus adalah ciptaan yang baru (2 Kor. 5:17). Mereka memiliki gaya hidup yang menyerupai umat Allah yang akan hadir dalam langit dan bumi yang baru (Ef. 4:24; Kol. 3:10). Hati orang percaya diubahkan terlebih dahulu, barulah kemudian pada waktu kedatangan Kristus kedua kalinya dibangkitkan dari antara orang mati dan mengalami perubahan secara fisik, yakni diberikan tubuh yang baru (Flp. 3:20-21).

Kehidupan orang percaya sebagai ciptaan yang baru senantiasa disertai dan dituntun oleh kehadiran Allah melalui Roh Kudus (Yoh. 16:4b-15). Paulus menekankan kesinambungan antara konsep Perjanjian Lama tentang kehadiran Allah melalui penggambaran bahwa orang percaya adalah bait Allah atau bait Roh Kudus (bdk. 1 Kor. 3:16; 6:19; 2 Kor. 6:16).$^{42}$ Gambaran ini sebenarnya telah dikatakan oleh Tuhan Yesus sendiri sebagai manusia yang sempurna, "Rombaklah Bait Allah ini dan aku akan membangunnya dalam tiga hari” (Yoh. 2:19-22). Hal ini menjadi jelas setelah kebangkitanNya, Yohanes memberikan penjelasan bahwa yang dimaksudkan Yesus adalah tubuhNya sendiri (Yoh. 2:21). ${ }^{43}$ Fakta ini menunjukkan bahwa Tuhan Yesus sendiri telah memberikan petunjuk bahwa orang percaya yang telah menerima anugerah penebusanNya adalah Bait Allah, yaitu tempat kehadiran Allah melalui Roh Kudus.

Paulus memberikan gambaran yang lebih jelas mengenai Bait Allah di dalam diri orang percaya. Di dalam 1 Korintus 3, Paulus menggabungkan gambaran taman di Eden

\footnotetext{
${ }^{42}$ Setelah Pentakosta, hadirat Allah berdiam di dalam umat-Nya sebagai bait Allah ketimbang dalam bangunan Bait Suci di sebuah lokasi geografis tertentu (Walton, Old Testament Theology, 122).

${ }^{43}$ Bdk. Dennis, "Temple of God," 28-29.
}

dan Bait Allah. ${ }^{44}$ Dalam ayat 6-7, Paulus menuliskan pekerjaan yang berkaitan dengan bercocok tanam, yakni menanam, menyiram, dan ada yang memberi pertumbuhan, yakni Allah sendiri (ay. 6-7). Gambaran ini merupakan lukisan dari tempat kudus Allah yang pertama di taman di Eden. Kemudian secara tiba-tiba Paulus masuk ke dalam metafora bangunan. Dia mengatakan bahwa orang percaya di Korintus adalah ladang Allah dan bangunan Allah. Setelah ini, Paulus menggunakan gambaran sebagai seorang ahli bangunan yang cakap telah meletakkan dasar dan orang lain membangun di atasnya (ay. 10; bdk. Kel. 35:31-32). Dasar yang telah diletakkan adalah Kristus dan kemudian orang membangun di atasnya dengan emas, perak, batu permata, kayu, rumput kering dan jerami (ay. 12-13). Jelaslah yang dapat bertahan adalah bendabenda berharga. Ini bukanlah simbolisasi bangunan biasa, tetapi ini adalah gambaran dari dasar Bait Allah yang dibangun dengan batu-batu yang mahal (1 Raj. 5:17; 1 Taw. 29:2) dan di dalam tempat kudus dilapisi dengan emas (1 Raj. 6:20-21). ${ }^{45}$ Gambaran yang dipakai oleh Paulus menunjukkan bahwa setiap pekerjaan pelayanan yang baik adalah bagian dari kehadiran Allah dalam tempat kudus-Nya. Umat percaya yang telah menerima penebusan Kristus pada masa kini memiliki dasar yang baru, yaitu Kristus yang telah menebus mereka. Paulus mendorong jemaat di Korintus untuk melihat bahwa pekerjaan Allah adalah pekerjaan bersama untuk pembangunan kerajaan-Nya. Kita semua, yakni bait-bait Allah yang mengalami kehadiran Allah di dalam diri kita akan dapat mengambil bagian di dalamnya tanpa rasa takut karena Allahlah yang akan membela bait-Nya (ay. 16-17).

Di dalam 1 Korintus 6:19, selanjutnya Paulus memakai gambaran bahwa tubuh orang

\footnotetext{
${ }^{44}$ Selengkapnya, lih. Beale, Temple and Church's Mission, 245-250.

${ }^{45}$ Ibid., 246-248.
} 
percaya adalah Bait Allah. Kata "tubuhmu" ( ò $\sigma \tilde{\omega} \mu \alpha \dot{v} \mu \tilde{\omega} v)$ dalam ayat ini memiliki tata bahasa yang menarik. Kata "tubuh" merupakan kata benda tunggal, sedangkan kata "kamu" adalah kata ganti jamak, sehingga lebih tepat diterjemahkan sebagai "tubuh dari kamu sekalian." Nijay Gupta menjelaskan bahwa hal ini menunjukkan bahwa Paulus ingin menekankan bahwa tubuh dari setiap orang percaya adalah bagian dari komunitas orang percaya yang satu. Di dalam Bait Allah yang adalah tubuh kita, Roh Kudus berdiam. Tubuh kita adalah tempat kudus Allah di mana Allah hadir. ${ }^{46}$

Mengapa dalam bagian ini Paulus memakai bahasa yang berkaitan dengan penyembahan di dalam tempat kudus Allah? Paulus menekankan akan kekudusan dari setiap orang percaya yang hidup bersama Allah yang kudus (2 Kor. 6:16).$^{47}$ Kehadiran Roh Kudus di dalam diri orang percaya membuat kita harus menjaga kekudusan hidup kita. Konteks dari 1 Korintus 6:12-19 jelas menghindarkan segala kenajisan, khususnya dalam bagian ini adalah percabulan. Kehadiran Tuhan mengharuskan kekudusan hidup umat-Nya.

\section{Kehadiran Allah dalam Langit dan Bumi yang Baru}

Deskripsi tempat kudus Allah selanjutnya adalah langit dan bumi baru (Why. 21:1-4). Langit dan bumi yang baru memiliki kesinambungan dengan gambaran tempat kudus Allah yang ada di dalam dunia ini, termasuk Taman Eden dan Tabernakel. ${ }^{48}$ Sebagaimana tempat kudus lainnya di bumi, materi yang dipakai menurut penglihatan rasul Yohanes adalah batu-batu mulia dan emas

\footnotetext{
${ }^{46}$ Nijay K. Gupta, "Which 'Body' is a Temple (1 Corinthians 6:19)? Paul beyond the Individual/Communal Divide," The Catholic Biblical Quarterly 72 (2010): 523.

${ }^{47}$ Ibid., 530. Rasul Paulus merujuk jemaat Tuhan sebagai tempat kediaman Roh Allah (1 Kor. 3:16) yang mengimplikasikan karakteristik kekudusan gereja sebagai bait Allah (lih. Dennis, "Temple of God," 46-47).

${ }^{48}$ Lih. Hinckley, "Adam, Aaron," 12.
}

murni (Why. 21:19-21). Kota ini juga memiliki air kehidupan yang mengalir keluar dari takhta Anak domba (Why. 22:1) dan pohon kehidupan pun ada di sana seperti di Taman Eden (Why. 22:2).$^{49}$ Berbeda dengan gambaran tempat kudus di dalam dunia, di sana tidak lagi diperlukan cahaya kandil atau matahari karena tidak ada lagi malam dan Anak Domba itulah yang memberikan terang (Why. 21:2; 22:5).

Selain itu, Beale juga mengamati berbagai paralelisme antara visi nabi Yehezkiel tentang bait suci eskatologis dengan visi rasul Yohanes tentang penciptaan baru. ${ }^{50}$ Pertama, Allah bertabernakel atau berdiam di antara umat-Nya (Why. 21:3 // Yeh. 43:7; 37:27; bdk. Im. 26:11-12). Kedua, gambaran terang kemuliaan Allah yang memenuhi baik ciptaan yang baru maupun Bait Suci (Why. 21:11, 23 // Yeh. 43:2-5). Ketiga, adanya dua belas pintu gerbang di empat penjuru mata angin (Why. 21:12-13 // Yeh. 48:31-34). Keempat, penerima penglihatan menerima perintah untuk mengukur bait-kota (Why. 21:15 // Yeh. 40:3-5). Kelima, kota atau tempat kudus berbentuk persegi yang sama panjang dan lebarnya (Why. 21:16 // Yeh. 45:1-5; 40:5; 41:21; 48:8-13; bdk. Za. 2:2). Keenam, air kehidupan yang mengalir dari Bait Suci (Why. 22:1-2a // Yeh. 47:1-9; bdk. Kej. 2:10; Za. 14:8). Ketujuh, adanya gambaran pohon dengan buah dan daun yang menyembuhkan di kedua tepian sungai (Why. 22:2b // Yeh. 47:12; bdk. Kej. 2:9). Jadi, gambaran langit dan bumi yang baru dalam penglihatan rasul Yohanes berhubungan erat dengan gambaran Taman Eden dan penglihatan Yehezkiel tentang Bait Suci sebagai tempat kudus Allah.

Hal yang perlu diperhatikan adalah tidak adanya Bait Suci di Yerusalem yang baru karena Allah sendiri adalah Bait Sucinya

\footnotetext{
${ }^{49}$ Bdk. Beale, New Testament Biblical Theology, 554.

${ }^{50}$ Paralelisme yang disajikan di paragraf ini dirangkum dari Beale, New Testament Biblical Theology, 552553; Beale, Temple and Church's Mission, 350-351.
} 
(Why. 21:22). ${ }^{51}$ Menurut penglihatan rasul Yohanes, bentuk dari kota Yerusalem yang baru adalah kubus karena ukuran panjang, lebar, dan tingginya sama (Why. 21:16). Di dalam Alkitab, bangunan lain yang berbentuk kubus adalah ruang mahakudus dalam Bait Allah (1 Raj. 6:20). ${ }^{52}$ Hal ini berarti bahwa Yerusalem yang baru adalah ruang mahakudus Allah di mana Allah bertakhta.

Gambaran di dalam kitab Wahyu ini merupakan kelanjutan dari gambaran-gambaran sebelumnya di Alkitab mengenai kehadiran Allah di tempat kudus. Hal ini berarti bahwa orang-orang percaya tinggal di Yerusalem yang baru berdiam di hadirat takhta Allah di ruang mahakudus. Gambaran dari langit dan bumi yang baru ini menunjukkan bahwa dari penciptaan sampai kepada kehidupan kekal bersama dengan Allah, Tuhan hadir di tengah umat-Nya. Penelusuran terhadap gambaran alkitabiah tentang kehadiran Allah ini memberikan kepada kita suatu keyakinan bahwa Allah ingin dekat dengan manusia sejak penciptaan yang pertama (Taman Eden) sampai dengan penciptaan yang baru (Yerusalem yang baru).

\section{HIDUP DALAM HADIRAT ALLAH DI DUNIA MASA KINI}

Setelah pemaparan gambaran biblikal bahwa Allah senantiasa hadir di tengah umat-Nya, penulis menarik dua implikasi untuk kehidupan kita sebagai bait dari Allah yang kudus di dalam dunia ini. Pertama, penekanan bahwa Allah hadir di dalam diri kita menuntut kehidupan yang kudus. Baik gambaran dalam Perjanjian Lama maupun dalam Perjanjian Baru menekankan bahwa kita harus senantiasa menjaga kekudusan. Sebagaimana yang diajarkan Alkitab, tidak ada kenajisan diperkenankan di dalam tempat kudus Allah. Oleh sebab itu, Adam diusir

${ }^{51}$ Lih. Hyde, God in Our Midst, 20.

${ }^{52}$ Lih. Beale, Temple and Church's Mission, 24; Beale, New Testament Biblical Theology, 552. dari taman di Eden. ${ }^{53}$ Kehadiran Allah di Kemah Suci dan Bait Suci menuntut kekudusan hidup sebagai umat Tuhan. Demikian pula, rasul Paulus memberikan penekanan yang sama. Semua ini menunjukkan bahwa orang percaya sebagai manusia baru harus hidup di dalam kekudusan dan kebenaran sebab tubuh kita adalah Bait Roh Kudus (Ef. 4:22-24; Kol. 3:5-17; 1 Kor. 6:19). Perintah ini terus berlanjut sampai kepada langit dan bumi yang baru sebagaimana tidak ada suatu pun yang najis yang dapat masuk ke dalam Yerusalem yang baru (Why. 21:8, 27).

Kedua, orang percaya adalah wakil Allah di dalam dunia ini. Adam yang pertama adalah perwakilan Allah di dalam dunia ini karena diciptakan menurut gambar dan rupa Allah (Kej. 1:26). Penemuan patung Hadad-yis'i di Tell Fakhriyah (Timur Laut Syria) memberikan pemahaman yang lebih jelas mengenai arti gambar dan rupa. Patung tersebut berasal dari abad ke-9 SM. Di dalam bagian bawah dari jubah dari patung ini tercantum inskripsi dalam dua bahasa. Di sebelah depan terdapat inskripsi berbahasa Akkadia (38 baris) dan di bagian belakangnya bahasa Aram (23 baris). ${ }^{54}$ Menurut deskripsi dari teks bahasa Akkadia Hadad-yis' $i$ adalah gubernur Asyur, sedangkan di dalam teks bahasa Aram, dia adalah raja dari Gozan dan Sikan. ${ }^{5}$ Inskripsi dalam patung tersebut menjelaskan bahwa patung tersebut adalah gambar dan rupa dari Hadad-yis'i. Sasson berpendapat bahwa gambar dan rupa adalah

${ }^{53}$ Lih. Dennis, "Temple of God," 7.

${ }^{54}$ Victor Sasson, "The Aramaic Text of the Tell Fakhriyah Assyrian-Aramaic Bilingual Inscription," Zeitschrift für die alttestamentliche Wissenschaft 97, no. 1 (1985): 86-87.

${ }^{55}$ Perbedaan antara keduanya dapat dijelaskan sebagai ketidaktersediaan kata yang sama untuk menerjemahkan istilah bahasa Akkadia ke dalam bahasa Aram atau menunjukkan bahwa dalam pandangan orang Asyur sebagai Hadad-yis'i adalah sekadar gubernur, tetapi bagi orang di Gozan dan Sikan adalah raja. Hal ini tercermin dari tulisan bahasa Akkadia yang ada di bagian depan patung dan terjemahan bahasa Aram terletak di belakangnya. Lih. Sasson, "The Aramaic Text," 86-87, 94, 94 n. 8, dan 99 n. 11. 
sinonim yang merujuk kepada patung tersebut. ${ }^{56}$ Patung itu sendiri merupakan representasi visual dari penguasa daerah tersebut, yakni Hadad-yis $i$.

Akan tetapi, Gentry memberikan penekanan yang sedikit berbeda. Menurutnya, istilah gambar dan rupa dalam inskripsi ini berkaitan namun memiliki nuansa yang berbeda. Rupa (likeness, bahasa Aram דמותא = bahasa Ibrani דמות) merujuk kepada dimensi vertikal yang menggambarkan hubungan dekat antara Allah (atau dewa) dengan manusia. Rupa Allah menegaskan manusia adalah anak Allah (bdk. Kej. 5:1-3; Luk. 3:38). Sedangkan gambar (image, bahasa Aram צלם = bahasa Ibrani צלם) merujuk kepada dimensi horizontal, hubungan antara manusia dengan dunia ciptaan di mana manusia diberikan kuasa dan status kerajaan untuk memerintah sebagai raja di bawah (mewakili) Allah atas dunia ciptaan. ${ }^{57}$ Pendapat Gentry ini menunjukkan bahwa manusia memiliki status yang khusus untuk mewakili Allah di dunia ini. Hubungan vertikal membuat Adam sebagai perwakilan yang sah dari Allah di dunia ini. Para raja di dalam dunia Timur Dekat Kuno biasanya membuat patung sebagai gambaran dirinya di daerahdaerah yang dikuasainya untuk menyatakan bahwa daerah tersebut ada di bawah kekuasaannya. ${ }^{58}$ Akan tetapi, menurut perspektif kitab Kejadian, perwakilan Allah di dalam dunia ini bukanlah patung raja atau pun berhala melainkan manusia sebagai gambar dan

\footnotetext{
${ }^{56}$ Sasson, "The Aramaic Text," 98.

${ }^{57}$ Selengkapnya, lih. Gentry, "Kingdom through Covenant," 28-33.

${ }^{58}$ Beale, Temple and Church's, 82-83. Gentry mengutip contoh yang diberikan oleh Hans Walter Wolff (Gentry, "Kingdom through Covenant," 32). Patung dari Firaun Rameses II yang ditatah di bukit nahr el-kelb di sebelah utara dari kota Beirut. Pemahaman yang sama dapat diberikan kepada patung dari raja Nebukadnezar dalam Daniel 3:1. Patung ini menunjukkan bahwa dia yang berkuasa di daerah tersebut. Lih. Hans Walter Wolff, Anthropology of the Old Testament (Philadelphia: Fortress, 1974), 160-161.
}

rupa Allah. ${ }^{59}$ Jikalau dalam pemahaman Timur Dekat Kuno anak ilah atau dewa umumnya hanya merujuk kepada para raja, Alkitab menunjukkan bahwa semua umat Allah adalah anak-anak Allah yang mewakili-Nya dalam memerintah dunia ciptaan.

Adam adalah wakil Allah untuk menjaga tempat kudus Allah di bumi ini dan mengembangkannya (Kej. 1:27-28; 2:15). Tugas Adam adalah untuk menjadikan seluruh bumi menjadi tempat yang dapat didiami (Yes. 45:18). Dapat didiami dalam pengertian bahwa seluruh bumi yang diciptakan Tuhan dapat mengalami kemuliaan Tuhan. Beale mengatakan, "God's ultimate goal in creation was to magnify his glory throughout the earth by means of his faithful image-bearers inhabiting the world in obedience to the divine mandate." 60 Tugas ini dapat dikatakan sebagai Amanat Agung yang pertama, yakni mendiami dunia sebagai gambar Allah yang taat dalam menyatakan kemuliaan Tuhan dan mewakili pemerintahan-Nya atas dunia.

Adam yang pertama gagal dalam melaksanakan tugas ini. ${ }^{61}$ Adam yang kedua, yakni Kristus, melaksanakan penebusan dengan kembali masuk ke dalam tempat kudus Allah di surga untuk membawa persembahan yang sejati (Ibr. 9:11-12, 24-26; bdk. Rm. 5:15-19). Setelah kemenangan dan kebangkitan-Nya, maka Adam yang kedua memberi Amanat Agung yang kedua kepada para murid-Nya (Mat. 28:19-20). Tugas gereja adalah menggenapi Amanat Agung ini sampai seluruh umat Tuhan akhirnya berkumpul di

\footnotetext{
${ }^{59}$ Pemahaman ini penting untuk memahami mengapa dalam hukum yang kedua dari Dasa Titah ada larangan untuk membuat patung pahatan untuk disembah (Kel. 20:4-5). Bukan hanya karena mereka adalah berhala, lebih dari itu, karena manusialah yang ditetapkan sebagai gambar atau perwakilan Allah yang memerintah atas dunia ini (bdk. Mzm. 8 dan Wolff, Anthropology of the Old Testament, 162-163).

${ }^{60}$ Beale, Temple and Church's Mission, 82. Bdk. Dennis, "Temple of God," 9.

${ }^{61}$ Beale dan Kim, God Dwells, 135.
} 
hadirat-Nya, di langit dan bumi yang baru, bersama dengan semua orang yang setia dari segala bangsa (Why. 7:9-17).

Di dalam situasi pandemi COVID-19, umat Tuhan tidak luput dari pergumulan dan dampak yang ditimbulkan oleh wabah ini. Penyertaan Allah atas umat-Nya mengingatkan pengharapan yang dimiliki umat Tuhan di dalam Kristus. Panggilan untuk hidup di dalam kekudusan tetap berlaku di dalam situasi wabah seperti ini, sebab identitas orang percaya adalah bait Roh Kudus. Di dalam masa sukar seperti ini, orang percaya perlu merenungkan kehidupan yang dijalani sampai sekarang ini dan menghadapi pertanyaan-pertanyaan tentang iman yang muncul di dalam diri sendiri maupun yang digumulkan sesama. Bagaimana umat Tuhan mewakili kebaikan, kasih, dan kemuliaan Allah di tengah dunia yang dilanda wabah? Bagaimana pengharapan Injil Yesus Kristus memberikan penghiburan bagi orang-orang yang sedang bergumul bahkan berduka? Bagaimana gereja menunjukkan relevansi pengharapan alkitabiah bahwa suatu hari kelak Tuhan Yesus akan datang kembali dan memulihkan segala sesuatu menjadi langit dan bumi yang baru? Kesadaran bahwa Allah tidak meninggalkan umat-Nya sekalipun wabah sedang melanda dunia ini membangkitkan pengharapan, rasa syukur, dan kekuatan untuk terus menjalani kehidupan iman sebagai pengikut Kristus. Allah Tritunggal senantiasa menyertai umat-Nya untuk menghadirkan kasih yang melayani sesama dan memberitakan Injil Kristus sampai kepada akhir zaman (bdk. Mat. 22:37-40; 28:19-20).

\section{KESIMPULAN}

Motif Alkitab yang dapat mempersatukan alur cerita dari PL sampai PB adalah kehadiran Tuhan di tengah umat-Nya. Penelusuran akan kehadiran Allah melalui tempat kudus-Nya memberikan suatu gambaran Alkitab yang tidak terputus akan kerinduan Allah untuk bersekutu dengan umat-Nya.
Tempat kudus pertama dalam Taman di Eden dan tempat kudus terakhir dalam kekekalan di Yerusalem yang baru menunjukkan hubungan yang indah dan interaksi langsung yang tidak dibatasi oleh dosa. Sedangkan tempat kudus yang ada setelah manusia jatuh dalam dosa, yakni Kemah Suci dan Bait Allah, merupakan kelanjutan dari tempat kudus yang pertama dan sebagai replika dari tempat kudus Allah di sorga. Di tempat kudus inilah manusia dapat memperoleh penyelesaian sementara atas dosa melalui persembahan. Kedatangan Tuhan Yesus yang pertama yang memberikan penyelesaian final atas dosa manusia sehingga Roh Kudus Allah dapat terus hadir di dalam dan menyertai setiap orang percaya sebagai baitNya. Gereja menjadi ciptaan baru yang bersiap untuk menyongsong kehidupan dalam kekekalan di Yerusalem yang baru.

Pemahaman tentang kerinduan Allah untuk hadir di tengah umat-Nya memberikan pengharapan yang pasti kepada gereja $\mathrm{Tu}-$ han untuk terus melangkah dalam iman dan melayani sesama dengan kasih. Allah Tritunggal menyertai umat-Nya melewati baik masa suka maupun masa duka di dalam kehidupan di dunia ini. Dalam situasi yang sangat sulit sekalipun, Allah akan terus memimpin umat-Nya untuk menghadirkan kasih-Nya di tengah-tengah dunia ini. Bahkan, suatu hari kelak, Allah akan sepenuhnya menghapuskan dosa dari dunia ini, memulihkan segala sesuatu, dan menghapuskan penderitaan dan air mata dari umat-Nya di langit dan bumi yang baru (Why. 21:1-4). Kiranya umat yang telah ditebus Tuhan Yesus terus hidup sebagai manusia baru di dalam kekudusan (Ef. 4:17-32; Kol. 3:5-17; 1 Kor. 6:19), mewakili pemerintahan Kerajaan Allah atas dunia ini (Kej. 1:27-28; 2:15; Mat. 28:19-20), dan bersiap untuk menikmati pengharapan tentang kehadiran Allah yang sepenuhnya di langit dan bumi yang baru (Why. 21-22). 


\section{DAFTAR KEPUSTAKAAN}

Beale, G.K. The Temple and the Church's Mission: A Biblical Theology of the Dwelling Place of God. New Studies in Biblical Theology. Downers Grove: InterVarsity, 2004.

- A New Testament Biblical Theology: The Unfolding of the Old Testament in the New. Grand Rapids: Baker Academic, 2011.

Beale, G.K., dan Mitchell Kim. God Dwells among Us: Expanding Eden to the Ends of the Earth. Downers Grove: InterVarsity, 2015.

Block, Daniel I. "Eden: A Temple? A Reassessment of the Biblical Evidence." Dalam From Creation to New Creation: Biblical Theology and Exegesis (Essays in Honor of G.K. Beale), diedit oleh Daniel M. Gurtner dan Benjamin L. Gladd, 3-32. Peabody: Hendrickson, 2013.

Dennis, Ryan S. "The Temple of God and the Early Christian Church.” Tesis, Reformed Theological Seminary, 2016.

Eichler, Raanan. "Cherub: A History of Interpretation," Biblica 96, no. 1 (2015): 26-38.

Fritz, Volkmar. "Temple Architecture: What Can Archaeology Tell Us About Solomon's Temple?" Biblical Archaeological Review 13, no. 4 (1987): 38-49.

Gentry, Peter J. "Kingdom through Covenant: Humanity as The Divine Image," The Southern Baptist Journal of Theology 12, no. 1 (2008): 16-42.

Haran, Menahem. Temples and Temple Service in Ancient Israel. Winona Lake: Eisenbrauns, 1985.

Hays, J. Daniel. The Temple and The Tabernacle: A Study of God's Dwelling Places from Genesis to Revelation. Grand Rapids: Baker, 2016.

Hinckley, Robert. "Adam, Aaron, and the Garden Sanctuary," Logia 22, no. 4 (2013): 5-12.

Hurowitz, Victor Avigdor. "YHWH's Exalted House-Aspects of the Design and Symbolism of Solomon's Temple." Dalam Temple and Worship in Biblical Israel.
Diedit oleh John Day, 63-110. London: T\&T Clark, 2007.

Hyde, Daniel R. God in Our Midst: The Tabernacle and Our Relationship with God. Sanford: Reformation Trust, 2012.

Koehler, Ludwig dan Walter Baumgartner. The Hebrew and Aramaic Lexicon of the Old Testament. Leiden: Brill, 2001.

Levenson, Jon D. Sinai and Zion: An Entry into the Jewish Bible. San Francisco: Harper, 1987.

Monson, John. "The New Ain Dara Temple: Closest Solomon Parallel," Biblical Archaeological Review 26, no. 3 (2000): 20-35.

Roxby, Philippa. "Coronavirus Confirmed as Pandemic." BBC News, 11 Maret 2020. https://www.bbc.com/news/world-51839944. Diakses 4 Mei 2020.

Sarna, Nahum. Exodus. The JPS Torah Commentary. Philadephia: The Jewish Publication Society, 1991.

Sasson, Victor. "The Aramaic Text of the Tell Fakhriyah Assyrian-Aramaic Bilingual Inscription." Zeitschrift für die alttestamentliche Wissenschaft 97, no. 1 (1985): 86-103.

Schachter, Lifsa. "The Garden of Eden as God's First Sanctuary." Jewish Bible Quarterly 41, no. 2 (2013): 73-77.

Walton, John H. The Lost World of Genesis One: Ancient Cosmology and the Origins Debate. Downers Grove: IVP Academic, 2009.

- Genesis 1 as Ancient Cosmology. Winona Lake: Eisenbrauns, 2011.

- Old Testament Theology for Christians: From Ancient Context to Enduring Belief. Downers Grove: InterVarsity, 2017.

Wenham, Gordon. "Sanctuary Symbolism in the Garden of Eden Story." Dalam I Studied Inscriptions from Before the Flood: Ancient Near Eastern, Literary, and Linguistic Approaches to Genesis 1-11. Diedit oleh Richard S. Hess dan David Toshio Tsumura. Winona Lake: Eisenbrauns, 1994.

Wolff, Hans Walter. Anthropology of the Old Testament. Philadelphia: Fortress, 1974. 